\title{
Analyzing the Eggs, Never Making an Omelet
}

\author{
Natasha Tar, Simon Fraser University
}

Reading itself was never a question or choice; I was introduced to books extremely early. My dad only reads the Bible and has always told me it's the only book worth reading. He read sections of it to me but stopped when I was around five because I became obsessed with Revelations, especially Revelation 12:3, which is a description of the devil. My mom didn't think the Bible was sufficient reading material, so she took me to the library. She tells me that my first word was "duck," and she guesses this is because she read The Tale of Jemima Puddle-Duck to me so often. I read this book many times growing up, but I didn't understand why it made me feel so conflicted. I was angry about what happened in the story: angry at Jemima's foolishness and naïveté, at her plight and her quick acceptance of circumstances, at the deceitful gentleman fox, and most of all at the awful puppies who come out of nowhere and eat her eggs. At some point, I realized this anger stemmed from confusion. The story was almost "Little Red Riding Hood," something I understood quite easily. But the ambiguities in Jemima Puddle-Duck prompted me to return to it again and again. There seemed to be a lot going on below the surface of the text that I couldn't reach and reasons for Jemima to act the way she did that I couldn't understand. Grappling with and revisiting confusing books informed my reading throughout childhood and continues today.

I've always needed a long time to answer questions. I admire those people whose hands shoot up moments after a question is asked. Meanwhile, an answer usually comes to me around dinner, long after I've left the classroom. When books started being assigned in elementary school, I would read ahead so I would have answers when we reached the assigned chapters. I wonder if reading all the time caused me to become so slow at answering questions. I took books' patience for granted; they let me chew on questions for as long as I needed to. It also didn't help that I gravitated towards books that confused me and prompted multiple readings. Two such series are $A$ Series of Unfortunate Events and The Adventures of Captain Underpants. I loved these series, and I still re-read parts of both fondly and find new things. At the time, I didn't question why I loved two 
disparate series equally. Now I see that they're both narratively interesting, with fun background details and chatty narrators.

That said, I read most things as a child: from Junie B. Jones to Ripley's Believe It or Not to plain old nonfiction shark books, I wasn't overly picky. Up until early high school, I would read books I hated or found boring to the very end. In this manner, I dragged myself through a lot of awful YA, such as Hot Pterodactyl Boyfriend. It felt wrong to leave behind a book once it was started. Sometimes I pushed myself through books because I found them difficult to read in another way. Wintergirls was my friend's favourite book. The book is a visceral look at depression, eating disorders, and suicide. I make myself read it every few years as a reminder of this pain's reality. I also struggled with The Absolutely True Diary of a Part-Time Indian when I first read it at age twelve. The masturbation references made me uncomfortable, but I knew the book as a whole was important. It was probably the first book I'd ever read by an Indigenous author about an Indigenous character.

Despite reading basically anything, I've always enjoyed magical realism the most. High fantasy and sci-fi never appealed to me. If the books weren't at least a little connected to our world (or at least a world very similar to ours), I would be disinterested. Maybe I believe that our world is interesting enough.

Instead of YA books, I tried to read classics in high school, most of which I found boring. I read The Lovely Bones at fourteen and decided I should wait a bit before trying more adult books because that book is... a lot. I then reverted to my reading roots and got back into comics, graphic novels, and manga. These were full of the fun narration and details that I've always loved. They encapsulated my teenage years much better than most YA fiction that was popular at the time. Since I was a cowardly prude who was disinterested in drugs and alcohol, I couldn't relate to or enjoy the stories of common YA novel protagonists. Katniss from The Hunger Games and Beatrice from Divergent are cold and relentless teenagers, the results of dystopian circumstances. All the other YA protagonists were having tons of sex, falling in love with boring people, or complaining about their parents. In comparison, the comics I read featured quieter moments of the teenage experience, the ones still rife with difficulties and complexities but conveyed without the snark and irony of the YA novels I came across. The Gentlemen's Alliance Cross and Kitchen Princess series featured protagonists who tried to keep in good spirits, nervously joined clubs, and faced problems with determination. Topics such as adoptive families, cruel classmates, and terminal 
illness weren't met with just cynicism, angst, and anger. They were examined from all angles, and characters were allowed to be conflicted and sad without being melodramatic. After reading these series with their admirable and subtle emotional cues, I developed a very deep hatred for John Green. The only book I've ever treated poorly was a library copy of Paper Towns that I threw out a fourth-floor apartment window before I finished reading it. In turn, I've never liked books that are constantly undermining any genuine moment that happens within them. I'm always looking for stories in which authors freely experiment with form and narration but don't feel the need to walk back vulnerable moments.

Near the end of high school, I was introduced to zines. My reading became split between formally published books and self-published works. The former were old friends. I read anthologies during that time, which I thought of affectionately as the mixtapes of books. But the latter came with a more complex relationship than reader/work. Going to a zine fair meant chatting with the creator, who was sitting in front of you at a table or booth. It meant flipping through their book, laughing, pointing to a specific drawing or poem and saying, "That's so great!" In the end, you would probably buy all of their zines, which would only cost you about $\$ 25$. Over the years, you'd see them at other fairs and get to know them. The zines are only a small part of the interaction but are still deeply satisfying. Most often they're personal and earnest. Matthew Bogart's Incredible Doom series is one of my favourites. Anything by Kathleen Gros and Cole Pauls is delightful. Zine makers were also my first real exposure to writers who were LGBTQ+. Now with diverse books being widely available and celebrated, I feel like I'm constantly playing catch-up and reevaluating the world and privilege I took for granted as a child.

My reading was guided by characters who questioned things constantly and were often confused, but not trying to hide this confusion behind apathy or other façades. Other than that, I think I've always admired books that try new things, narratively and through physical design. If I were to psychoanalyze myself, I guess it would make sense to say that I was looking for things in books that I was lacking in real life: honesty and novelty.

Pursuing an English major was my second choice. I wanted to be a baker, but after two years at a bakery, I decided it wasn't the life for me. Reading, and by extension writing, was my only other constant and passion. I had seen Vancouver's community of small presses, magazines, and self-publishers and decided being part of that world looked interesting. Maybe a literature degree 
would also help unravel the mysteries of all those confusing books. My parents thought I was throwing my money away by going to university. But my dad had seen my love of reading and writing and begrudgingly admitted I could probably make something of myself by studying these things. Though he's still upset I haven't read the Bible.

I'm now in the second-to-last semester of my degree and sometimes I feel like it was wasted on me. I've found academia overall more prescriptive than exploratory. I will probably never go back to university. The world has lots to teach without the price tag and desperate struggle to be seen as smart. Bitterness aside, I'm grateful overall for the experience and I've tried to get lots out of my degree. I'm sure I could now write a decent paper on The Tale of Jemima PuddleDuck, analyze it for themes of rape or the price of motherhood or something like that. But honestly, I could probably read it a thousand times and still not fully understand it. It will still confuse and anger me. And I'm glad for that.

(C) Natasha Tar, 2021 